\title{
African provenance for the metasediments and metaigneous rocks of the Cyclades, Aegean Sea, Greece
}

\author{
Sue Keay* Department of Earth Sciences, University of Queensland, St. Lucia, QLD 4072, Australia \\ Gordon Lister Australian Crustal Research Centre, Monash University, Clayton, VIC 3128, Australia
}

\begin{abstract}
$\mathrm{U}-\mathrm{Pb}$ geochronology on detrital and inherited zircons from metasediments as well as gneissic and metaigneous basement rocks of the Cyclades, Aegean Sea, Greece, defines several periods of crustal growth prior to the Carboniferous. These ages are consistent with Cycladic rocks being derived from the northern margin of Gondwana. There is a distinct Mesoproterozoic age gap evident in zircons from the 25 samples considered. This is characteristic of the West African craton, and we suggest it will also prove characteristic of the Aegean region. This Mesoproterozoic age gap may be used as a tool in terrane reconstruction to distinguish crustal material derived from different parts of Gondwana.
\end{abstract}

Keywords: zircon, geochronology, provenance, Cyclades, tectonic models.

\section{INTRODUCTION}

Dating detrital minerals in sediments is a common method used to determine sedimentary provenance (Hurley et al., 1961), to define periods of crustal growth (Tatsumoto and Patterson, 1964), or to trace the origin of allochthonous terranes (Krogh and Keppie, 1990). Attempts to trace crustal evolution have also been made by dating inherited zircon grains in granites (Pidgeon and Aftalion, 1978) and orthogneisses (Compston and Kröner, 1988). In this paper the crustal evolution of rocks from the Cyclades, Aegean Sea, Greece, is determined by dating detrital and inherited zircons from gneissic basement and overlying tectonic slices of metasediments and metavolcanic units. This is the first study to define the early geological evolution of $\mathrm{Cy}$ cladic continental crust.

In pre-Mesozoic time, the continental blocks of the Hellenides (including the Cyclades) (Fig. 1) are thought to have formed part of the northern margin of Africa (see Robertson and Dixon, 1984). Tracing the dispersal of microcontinental blocks derived from the northern margin of Gondwana is difficult due to their complex geological histories. PreMesozoic plate reconstructions are particularly difficult (Dercourt et al., 1986), given that the outcrop patterns have been disrupted by the Variscan and Alpine orogenic events, and paleontological and paleomagnetic controls in many areas such as the Cyclades are absent (Dürr et al., 1978; Morris and Anderson, 1996). However, the general location of the major continental blocks is well defined, and the Precambrian geological evolution of the Cyclades is expected to be broadly similar to that of the sparsely dated North African crust.

\footnotetext{
*Corresponding author's e-mail: sue@earth.uq
} edu.au.

\section{GEOLOGIC SETTING}

Metamorphic core complexes in the Cyclades form the central part of the AtticCycladic Massif, which extends through the central Aegean from Attica in southeastern Greece to Turkey (Fig. 1). Correlations between the Pelagonian zone, the Menderes Massif, and the Cyclades have been suggested due to the geological similarities between these terranes (Fig. 1) (Papanikolaou and Demirtasli, 1987; Candan et al., 1997). While complicated structures make it difficult to correlate between islands, three main lithological groups have been distinguished (Fig. 2) (Dürr et al., 1978). An upper unit at the highest structural levels usually occupies the lowest topography as scattered outcrops of faultjuxtaposed unmetamorphosed sedimentary and ophiolitic rocks. At structurally intermediate levels the Mesozoic series consist of a sequence of intensely deformed platform sediments, including neritic carbonates, psammitic to pelitic sediments, and volcanics metamorphosed to eclogite-blueschist facies. The above units structurally overlie an inferred pre-Alpidic basement consisting of complex schists, gneisses, and amphibolites (Andriessen et al., 1987; Henjes-Kunst and Kreuzer, 1982) (Fig. 1).

These different tectonic slices have been juxtaposed along low-angle normal faults forming metamorphic core complexes (Lister et al., 1984). Basement and series rocks have undergone at least two sequences of regional metamorphic events. A sequence of high-pressure blueschist to eclogite facies metamorphic episodes $\left(\mathrm{M}_{1 \mathrm{~A}}-\mathrm{M}_{1 \mathrm{D}}\right)$ occurred from ca. 65 to $32 \mathrm{Ma}$, followed (ca. 32-15 Ma) by a se-



Figure 1. Generalized tectonic map of Aegean region (modified from Dürr et al., 1978; Robertson and Dixon, 1984). Inset shows location of Cycladic islands between Greece and Turkey, part of Attic-Cycladic massif, possible extension of Menderes Massif, and Pelagonian zone. Seven islands from which analyzed samples were obtained are highlighted. 


UPPR UNIT
granitoid

Figure 2. Schematic stratigraphic column showing three main lithological units found in the Cyclades. From oldest to youngest, these include basement composed of garnet-mica schists intruded by Paleozoic granitoids, series rocks composed of Mesozoic sedimentary sequences intruded by Miocene granitoids, and upper unit of Mesozoic sediments, ophiolites, and granitoids.

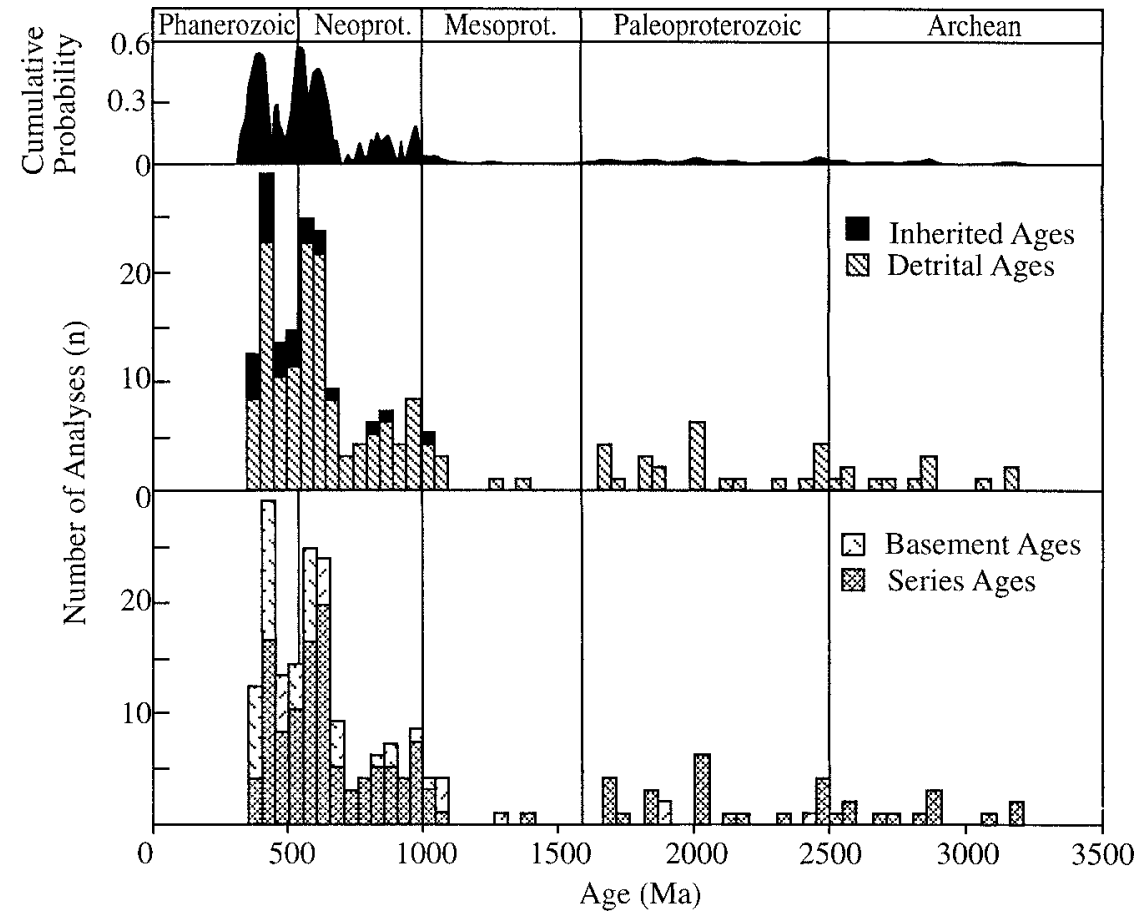

Figure 3. Pre-Carboniferous age distribution for detrital zircons from 17 samples of metasediment and inherited zircons from 8 samples of orthogneiss taken from 7 islands of Cyclades. Graph comprises kerned probability density curve and two histograms of age data using 50 m.y. bin widths. Probability density diagram illustrates major age peaks identified in text. Top histogram shows total number of pre-Carboniferous zircons $(n=201)$ with ages from metasediments $(n=177)$ and metaigneous $(n=24)$ samples distinguished, and bottom histogram shows total number of preCarboniferous zircons derived from basement $(n=57)$ and from series $(n=144)$. quence of Oligocene-Miocene medium-pressure greenschist metamorphism $\left(\mathrm{M}_{2}\right)$ that occasionally reached amphibolite facies and is locally overprinted by contact metamorphism associated with Miocene granitoid intrusion $\left(\mathrm{M}_{3}\right)$ from ca. 18 to $12 \mathrm{Ma}$ (Altherr et al., 1982; Andriessen et al., 1979; Henjes-Kunst and Kreuzer, 1982).

Despite the complexity of overprinting relationships, some evidence of a pre-Alpine history for the lower plate rocks can be established on the basis of texture. Relicts of an earlier $\left(\mathrm{M}_{0}\right)$ amphibolite facies metamorphism have been described on Ios (Henjes-Kunst and Kreuzer, 1982). The existence of pre-Alpine basement material has been postulated for the islands of Sikinos (van der Maar et al., 1981), Naxos (Andriessen et al., 1987), Mykonos, Paros, Serifos, and Syros (van der Maar and Jansen, 1983). The identification of pre-Mesozoic basement in the Aegean provides a starting point for the early geological history of the Cyclades, but age information from this basement is confined to post-Carboniferous. Here we present ages derived from zircons from 25 samples that have undergone the Alpine orogenic cycle, i.e., the basement and Mesozoic series units. We consider these units representative of the pre-Carboniferous crustal signature of the area, although they may not be genetically related.

\section{SAMPLE SELECTION AND U-Pb ANALYTICAL RESULTS}

More than 700 analyses were conducted on 560 zircons extracted from 25 samples yielding 201 pre-Carboniferous ages ${ }^{1}$. U-Pb compositions were measured using the Australian National University's SHRIMP I and II ion microprobes. The samples included 17 metasediments and 8 orthogneisses from 7 different islands, Folegandros, Ios, Naxos, Paros, Sifnos, Sikinos, and Syros (Fig. 1). PreCarboniferous ages $(n=201)$ were derived from both detrital zircons in metasediments ( $\mathrm{n}$ $=177$ ) or from inherited cores in magmatic zircons separated from orthogneisses ( $\mathrm{n}=$ 24). The zircons of 12 samples of basement yielded 57 pre-Carboniferous ages from 179 analyses, and 13 samples of series rocks yielded 144 pre-Carboniferous ages from 522 analyses.

The ages from all 25 samples have been combined and a summary of major zircon age components older than Carboniferous is graphically displayed in Figure 3. Only scattered peaks are recognizable in the Paleoproterozoic and Archean, reflecting the relatively

${ }^{1}$ GSA Data Repository item 2002019, SHRIMP analytical technique and $\mathrm{U}-\mathrm{Pb}$ analytical results, is available on request from Documents Secretary, GSA, P.O. Box 9140, Boulder, CO 80301-9140, USA, editing@geosociety.org, or at www. geosociety.org/pubs/ft2002.htm. 
small number of analyses ( $\mathrm{n}=26$ and 12, respectively). The two oldest ages measured, ca. 3170 and $3190 \mathrm{Ma}$, are from two metasedimentary units sampled from Naxos and Folegandros. Several peaks can be identified: ca. 2900-2850, 2500-2450, 2050-2000, 1900-1800, and 1700-1650 Ma. Of these Paleoproterozoic and Archean ages, 16 of the 38 analyses were from obvious xenocrystic cores and the other analyses generally came from irregularly zoned grains.

There is a distinct paucity of Mesoproterozoic ages in the zircon populations. Only 10 zircons yielded ages in the range 1600-1000 $\mathrm{Ma}$, and these were from metasedimentary units on Naxos, Ios, and Folegandros. A significant age gap is apparent from ca. 1600 to $1400 \mathrm{Ma}$, and a complicated distribution of ages occurs between 1100 and $700 \mathrm{Ma}$; two peaks are distinguishable ca. 1000-950 and 900-800 Ma. Mixture of modeling and ageprobability density diagrams of the age range 500-700 Ma reveal two age populations ca. 650 and $550 \mathrm{Ma}$. There is one pre-Carboniferous Paleozoic peak in the range ca. 450-400 Ma. The peaks are all defined by more than 20 individual analyses; ages younger than 650 Ma compose more than half $(n=114)$ of the total number of analyses $(n=201)$. The most prominent peaks from the combined analyses are also the youngest due to the better preservation potential of younger zircons.

\section{DISCUSSION}

The dominant inherited and detrital zircon age populations visible in Figure 2 can be used to characterize the crustal precursors from which basement and series rocks of the Cyclades were ultimately derived. Unfortunately, little work has been published on inherited zircon age populations for the Alpine orogens, making correlations between areas difficult. Some ion-probe analyses of preMesozoic detrital, metamorphic, and igneous zircons from a range of rock types in the Moldanubian and Massif Central (Gebauer et al., 1989; Gebauer, 1993) have been used to define the pre-Mesozoic evolution of central European continental crust. This crust, like that of the Cyclades, is thought to have been derived from the northern margin of Gondwana because of the predominance of Pan-African ages found, here defined as in the range 650$550 \mathrm{Ma}$.

In the European Variscides, Gebauer (1993) distinguished four Precambrian megacycles of crustal development as ca. 2700-2500, 22001900, 1200-900, and 800-550 Ma, and interpreted the abundance of Pan-African ages as evidence that the Variscides were derived from the supercontinent Gondwana rather than Laurasia. In contrast, the Laurasian crust of the Scandanavian Caledonides lacks Pan-
African ages and yields Mesoproterozoic ages (Williams and Claesson, 1987), which are lacking in the age populations of the European Variscides and their southern extension in the Cyclades. The Mesoproterozoic age gap in the Cyclades is consistent with its derivation from the northern margin of Gondwana (presentday North Africa) and reflects a lack of material of this age in the area (Cahen et al., 1984). The absence of Mesoproterozoic ages is also distinctive of West Africa crust and has been used to identify the origin of suspect terranes from West Gondwana in the Western Cordillera of North America (Nance and Murphy, 1994).

Similarly, Gebauer (1993) distinguished the period between ca. 1700 and $1200 \mathrm{Ma}$ as one of tectonic quiescence in the European Variscides, and suggested that this is typical for the non-Australian part of Gondwana, presumably West Gondwana. A Gondwana component containing Proterozoic age peaks ca. 17001400 and $1150-1000 \mathrm{Ma}$ is shared by Paleozoic sediments from New Zealand, eastern Australia, and Antarctica (Ireland, 1992; Wysoczanski et al., 1997). The occurrence of Mesoproterozoic zircon ages, which presumably record important tectonomagmatic events in segments of East Gondwana and in the Amazonian craton (Teixera et al., 1989), suggests that an important distinction can be made between zircon populations of these areas and those of North and West Africa.

Neoproterozoic ages in the range 900-700 $\mathrm{Ma}$ are considered to be characteristic of North African and Arabian crust (Kröner and Şengör, 1990). Such ages are derived from primitive magmatic rocks produced during the development of an active continental margin and associated island arcs (Reischmann et al., 1991). The identification, in this study, of a significant population of zircons of Neoproterozoic age supports a close relationship between the Cyclades and North Africa and Arabia, where rocks in this age range are common (Cahen et al., 1984). This interpretation is consistent with proposed tectonic reconstructions of the area based on paleontological and lithological data (e.g., Robertson and Dixon, 1984). The latter would also place the Menderes Massif of western Turkey in close proximity to the Cyclades, also as part of the northern margin of Gondwana.

Such a tectonic model is supported by the similarities in Precambrian age patterns between the Cyclades and those reported for the Menderes Massif from conventional U-Pb zircon and single zircon $\mathrm{Pb}$ evaporation, which span ca. 2555-1740 and 1000-700 Ma (Reischmann et al., 1991). Pan-African ages are also common in both detrital and magmatic zircons from the Menderes Massif of western Turkey (Kröner and Şengör, 1990;
Hetzel and Reischmann, 1996), which would support the idea of an affinity between the rocks of western Turkey and the Cyclades. However, Kröner and Şengör (1990) reported a gap in zircon $\mathrm{Pb}$ evaporation ages from 900 to $700 \mathrm{Ma}$ for samples from the MenderesTaurus block of southern Turkey and suggested that this precludes derivation of the Menderes Massif from Africa, instead suggesting derivation from the East Sayan block of the Angara craton of Siberia. It is possible that a mélange of crustal blocks of different provenance exists in this area, but this is difficult to assess without further detailed provenance studies.

The megacycles recognized in the European Variscides are broadly similar to the age components found in the Cyclades; however, they differ in one important respect. Although PanAfrican ages are present, the European Variscides do not appear to contain a bimodal age population in the restricted ca. 650-550 Ma range, although future work may reveal its presence. Likewise, Cycladic zircon age patterns are bimodal in this range; two separate Pan-African events are distinguishable by objective mixture modeling and age-probability density diagrams ca. $650 \mathrm{Ma}$ and ca. $550 \mathrm{Ma}$.

The increased frequency of Pan-African zircons in the eastern Mediterranean region, as found in this study, may assist with the delineation of a belt defined by Pan-African tectonism at the margins of the European Variscides. Late Ordovician orogenic activity is widely documented in the European Variscides with granite intrusion ca. 460-440 Ma (Köppel et al., 1980), possibly related to collision of terranes separated from Gondwana after the Pan-African orogeny (Gebauer, 1993). There are few ages in the Menderes Massif that match the strong 450-400 Ma age group found in the Cyclades. In contrast, the Menderes Massif is thought to have remained relatively stable from the Early Ordovician to at least the Late Triassic (Şengör et al., 1984). The absence of 450-400 Ma ages in western Turkey suggests that while the precursors of both Cycladic and Menderes Massif crust had similar Precambrian histories, their Paleozoic histories are distinctly different (cf. Ring et al., 1999). This should be an important consideration in plate reconstructions of the eastern Mediterranean and is not adequately addressed by established models (e.g., Robertson and Dixon, 1984; Kröner and Şengör, 1990).

\section{CONCLUSIONS}

Zircons from Paleozoic sediments and orthogneisses from the Cyclades record complex growth histories that provide information about the source from which these rocks were derived. Zircon age patterns for the Cyclades and western Turkey show similarities for the 
Precambrian, but distinct differences in the Paleozoic. The lack of published pre-Mesozoic age data for other areas precludes detailed comparisons being made with the Cyclades. Nevertheless it can be concluded that the Cycladic age pattern is similar to that reported for the European Variscides. The preponderance of Pan-African ages in Cycladic rocks suggests affinities with Gondwana rather than Laurasia, consistent with an interpretation of the Cyclades being derived from the northern margin of Gondwana (currently North Africa). The Cycladic age pattern is hence indicative of North Gondwana. The distinctive Mesoproterozoic age gap found in zircons from $\mathrm{Cy}$ cladic rocks is also found in the West African craton and is a feature that should prove characteristic of North Gondwana crust. The Mesoproterozoic age gap makes it possible to distinguish North and West Africa crust from that derived from other parts of Gondwana, making it a useful tool for tectonic reconstructions.

\section{ACKNOWLEDGMENTS}

Vaois Avdis, Adonis Photiades, and Sue Baldwin kindly supplied samples; Bill Compston, Richard Wysoczanski, and Paul Hoskin made valuable comments on an early version of this paper, which was substantially improved by the reviews of L. Peter Gromet and George Gehrels. This research was supported by an Australian Postgraduate Research Award and Jaeger Scholarship from the Research School of Earth Sciences, Australian National University to Keay and an Australian Research Council grant to Lister.

\section{REFERENCES CITED}

Altherr, R., Kreuzer, H., Wendt, I., Lenz, H., Wagner, G.A., Keller, J., Harre, W., and Hohndorf, A., 1982, A late Oligocene/early Miocene high temperature belt in the Attic-Cycladic crystalline complex (SE Pelagonian, Greece): Geologisches Jahrbuch, v. E23, p. 97-164.

Andriessen, P.A.M., Boelrijk, N.A.I.M., Hebeda, E.H., Priem, H.N.A., Verdurmen, E.A.T., and Verschure, R.H., 1979, Dating the events of metamorphism and granite magmatism in the Alpine orogen of Naxos (Cyclades, Greece): Contributions to Mineralogy and Petrology, v. 69 , p. 215-225.

Andriessen, P.A.M., Banga, G., and Hebeda, E.H., 1987, Isotopic age study of pre-Alpine rocks in the basal units on Naxos, Sikinos and Ios, Greek Cyclades: Geologie en Mijnbouw, v. 66, p. 3-14.

Cahen, L., Snelling, N.J., Delhal, J., and Vail, J.R., 1984, The geochronology and evolution of Africa: Oxford, Clarendon Press, 512 p.

Candan, O., Dora, Ö.O., Oberhänsli, R., Oelsner, F., and Dürr, S., 1997, Blueschist relics in the Mesozoic cover series of the Menderes Massif and correlations with Samos Island, Cyclades: Schweizerische Mineralogische und Petrographische Mitteilungen, v. 77, p. 95-99.

Compston, W., and Kroner, A., 1988, Multiple zircon growth within early Archean tonalitic gneiss from the Ancient Gneiss complex, Swaziland: Earth and Planetary Science Letters, v. 87, p. 13-28.

Dercourt, J., Zonenshain, L.P., Ricou, L.-E., Kazmin, V.G., Le Pichon, X., Knipper, A.L.,
Grandjacquet, C., Sbortshikov, I.M., Geyssant, J., Lepvrier, C., Pechersky, D.H., Boulin, J., Sibuet, J.-C., Savostin, L.A., Sorokhtin, O., Wetsphal, M., Bazhenov, M.L., Lauer, J.P., and Biju-Duval, B., 1986, Geological evolution of the Tethys belt from the Atlantic to the Pamirs since the Lias: Tectonophysics, v. 123, p. 241-315.

Dürr, S., Altherr, R., Keller, J., Okrusch, M., and Seidel, E., 1978, The median Aegean crystalline belt: Stratigraphy, structure, metamorphism, magmatism, in Closs, H., et al., eds., Alps, Apennines, Hellinides: Inter-union Commission on Geodynamics scientific report 38: Stuttgart, E. Schweizerbaurt'sche Verlagsbuchhandlung, p. 455-477.

Gebauer, D., 1993, The Pre-Alpine evolution of the continental crust of the Central Alps-An overview, in Raumer, J.F.v., and Neubauer, F., eds., Pre-Mesozoic geology in the Alps: Berlin, Springer-Verlag, p. 93-117.

Gebauer, D., Williams, I.S., Compston, W., and Grunenfelder, M., 1989, The development of the Central European continental crust since the Early Archean based on convectional and ion-microprobe dating of up to 3.84 b.y. old detrital zircons: Tectonophysics, v. 157, p. 81-96.

Henjes-Kunst, F., and Kreuzer, H., 1982, Isotopic dating of pre-Alpidic rocks from the island of Ios (Cyclades, Greece): Contributions to Mineralogy and Petrology, v. 80, p. 245-253.

Hetzel, R., and Reischmann, T., 1996, Intrusion age of Pan-African augen gneisses in the southern Menderes Massif and the age of cooling after Alpine ductile extensional deformation: Geological Magazine, v. 133, p. 565-572.

Hurley, A.M., Brookins, D.G., Pinson, W.H., Hart, S.R., and Fairbairn, H.W., 1961, K-Ar age studies of Mississippi and other river sediments: Geological Society of America Bulletin, v. 72, p. 1807-1816.

Ireland, T.R., 1992, Crustal evolution of New Zealand: Evidence from age distributions of detrital zircons in Western Province paragneisses and Torlesse greywacke: Geochimica et Cosmochimica Acta, v. 56, p. 911-920.

Köppel, V., Günthert, A., and Grünenfelder, M., 1980, Patterns of U-Pb zircon and monazite ages in polymetamorphic units of the Swiss Central Alps: Schweizerische Mineralogische und Petrographische Mitteilungen, v. 61, p. 97-119.

Krogh, T.E., and Keppie, J.D., 1990, Age of detrital zircon and titanite in the Meguma Group, southern Nova Scotia, Canada: Clues to the origin of the Meguma Terrane: Tectonophysics, v. 177 , p. 307-323.

Kröner, A., and Şengör, A.M.C., 1990, Archean and Proterozoic ancestry in late Precambrian to early Paleozoic crustal elements of southern Turkey as revealed by single-zircon dating: Geology, v. 18, p. 1186-1190.

Lister, G.S., Banga, G., and Feenstra, A., 1984, Metamorphic core complexes of Cordilleran type in the Cyclades, Aegean Sea, Greece: Geology, v. 12, p. 221-225.

Morris, A., and Anderson, M., 1996, First palaeomagnetic results from the Cycladic Massif, Greece, and their implications for Miocene extension directions and tectonic models in the Aegean: Earth and Planetary Science Letters, v. 142 , p. $397-408$.

Nance, R.D., and Murphy, J.B., 1994, Contrasting basement isotopic signatures and the palinspastic restoration of peripheral orogens: Ex- ample from the Neoproterozoic AvalonianCadomian belt: Geology, v. 22, p. 617-620.

Papanikolaou, D.J., and Demirtasli, E., 1987, Geological correlations between the Alpine segments of the Hellenides-Balkanides and Taurides-Pontides, in Flugel, H.W., et al., eds., Pre-Variscan and Variscan events in the Alpine-Mediterranean Mountain Belts: Bratislava, Alfa Publishers, p. 387-396.

Pidgeon, R.T., and Aftalion, M., 1978, Cogenetic and inherited zircon U-Pb systems in Palaeozoic granites from Scotland and England, in Bowes, D.R., and Leake, B.E., eds., Crustal processes and evolution in N.W. Britain and adjacent regions: Geological Journal, v. 10, Special issue, p. 183-220.

Reischmann, T., Kröner, A., Todt, W., Dürr, S., and Şengör, A.M.C., 1991, Episodes of crustal growth in the Menderes Massif, W. Turkey, inferred from zircon dating: Terra Abstracts, v. 3 , p. 34 .

Ring, U., Gessner, K., Gungor, T., and Passchier, C.W., 1999, The Menderes Massif of western Turkey and the Cycladic Massif in the Aegean; do they really correlate?: Geological Society [London] Journal, v. 156, p. 3-6.

Robertson, A.H.F., and Dixon, J.E., 1984, Introduction: Aspects of the geological evolution of the Eastern Mediterranean, in Dixon, J.E., and Robertson, A.H.F., eds., The geological evolution of the Eastern Mediterranean: Geological Society [London] Special Publication 17, p. $1-74$.

Şengör, A.M.C., Satir, M., and Akkok, R., 1984, Timing of tectonic events in the Menderes Massif, Western Turkey: Implications for tectonic evolution and evidence for Pan-African basement in Turkey: Tectonics, v. 3, p. 693-707.

Tatsumoto, M., and Patterson, C., 1964, Age studies of zircon and feldspar concentrates from the Franconia sandstone: Journal of Geology, v. 72, p. 232-242.

Teixera, W., Tassinari, C.C.G., Cordani, U.G., and Kawashita, K., 1989, A review of the geochronology of the Amazonian craton: Tectonic implications: Precambrian Research, v. 42, p. 213-227.

van der Maar, P.A., and Jansen, J.B.H., 1983, The geology of the polymetamorphic complex of Ios, Cyclades, Greece, and its significance for the Cycladic Massif: Geologische Rundschau, v. 72, p. 283-299.

van der Maar, P.A., Feenstra, A., Manders, B., and Jansen, J.B.H., 1981, The petrology of the island of Sikinos, Cyclades, Greece, in comparison with that of the adjacent island of Ios: Neues Jahrbuch Mineralogische Montaschafte, v. 1981 , p. $459-469$.

Williams, I.S., and Claesson, S., 1987, Isotopic evidence for the Precambrian provenance and Caledonian metamorphism of high grade paragneisses from the Seve Nappes, Scandanavian Caledonides: Contributions to Mineralogy and Petrology, v. 97, p. 205-217.

Wysoczanski, R.J., Gibson, G.M., and Ireland, T.R., 1997, The distinction of source components in Paleozoic sediments from northwest Nelson, New Zealand, and their relevance to the paleoPacific Gondwana margin: Geology, v. 25, p. 939-942.

Manuscript received July 12, 2001

Revised manuscript received October 30, 2001

Manuscript accepted November 26, 2001

Printed in USA 